\title{
PENERAPAN MODEL STAD BERBANTU MEDIA SAC UNTUK MENINGKATKAN MOTIVASI DAN HASIL BELAJAR PESERTA DIDIK
}

\author{
SRI PUJIASTUTI \\ SMA Negeri 3 Pemalang \\ e-mail: sripujiastuti334@gmail.com
}

\begin{abstract}
ABSTRAK
Penelitian ini bertujuan untuk mendeskripsikan penerapan model STAD berbantu media SAC pada materi pertumbuhan dan pembangunan ekonomi dalam upaya meningkatkan motivasi dan hasil belajar peserta didik. Subjek penelitian ini adalah peserta didik kelas XI.MIPA SMA Negeri 3 Pemalang, yang berjumlah 36 peserta didik diantaranya 13 laki-laki dan 23 perempuan. Jenis penelitian ini adalah penelitian Tindakan kelas. Hasil penelitian menunjukkan bahwa motivasi belajar peserta didik pada siklus I sebesar 59,95\% sedangkan siklus II motivasi belajar meningkat sebesar $81,10 \%$. Peningkatan motivasi peserta didik dipengaruhi oleh penggunaan model pembelajaran STAD yang berbantu media pembelajaran mobile berbasis SAC. Sedangkan hasil belajar rata-rata peserta didik terjadi peningkatan dari 69,72 atau $75 \%$ sudah mencapai KKM dan 25\% belum mencapai KKM pada siklus I menjadi 84,31 atau $86,11 \%$ sudah mencapai KKM dan $13,89 \%$ belum memcapai KKM pada siklus II dengan standar nilai KKM yang sudah ditentukan yaitu 70. Perubahan hasil belajar peserta didik yang mengalami peningkatan dipengaruhi oleh penggunaan model pembelajaran STAD berbantu media pembelajaran mobile berbasis SAC yang mempengaruhi motivasi belajar yang tinggi dari peserta didik. Dengan demikian dapat disimpulkan bahwa penerapan model STAD berbantu SAC dapat meningkatkan motivasi dan hasil belajar pada materi pertumbuhan dan pembanggunan ekonomi pada kelas XI.MIPA1 di SMA Negeri 3 Pemalang.
\end{abstract}

Kata Kunci: STAD, SAC, Motivasi, Hasil Belajar

\section{ABSTRACT}

This study aims to describe the application of the STAD model assisted by SAC media on the material of economic growth and development in an effort to increase students' motivation and learning outcomes. The subjects of this study were students of class XI.MIPA SMA Negeri 3 Pemalang, totaling 36 students including 13 males and 23 females. This type of research is classroom action research. The results showed that the learning motivation of students in the first cycle of $59.95 \%$ while the second cycle of learning motivation increased by $81.10 \%$. The increase in students' motivation is influenced by the use of the STAD learning model which is assisted by SAC-based mobile learning media. While the average learning outcomes of students have increased from 69.72 or $75 \%$ have reached the KKM and $25 \%$ have not reached the KKM in the first cycle to 84.31 or $86.11 \%$ have reached the KKM and $13.89 \%$ have not reached the $\mathrm{KKM}$ in the first cycle. cycle II with the standard KKM value that has been determined is 70 . Changes in student learning outcomes that have increased are influenced by the use of the STAD learning model assisted by SAC-based mobile learning media which affects the high learning motivation of students. Thus, it can be concluded that the application of the STAD model assisted by SAC can increase motivation and learning outcomes in the material on economic growth and development in class XI.MIPA1 at SMA Negeri 3 Pemalang.

Keywords: STAD, SAC, Motivation, Learning Outcomes

\section{PENDAHULUAN}

Pendidikan dan pengajaran merupakan suatu proses yang sadar tujuan. Tujuan mempunyai arti sebagai suatu usaha untuk memberikan rumusan hasil yang diharapkan peserta didik setelah melaksanakan pengalaman belajar. Salah satu tercapainya tujuan pengajaran adalah melalui prestasi belajar yang diraih peserta didik. Peserta didik yang berindikasi berpengetahuan baik biasanya prestasi nya tinggi. Salah satu faktor yang mempengaruhi 
prestasi belajar peserta didik adalah motivasi belajar. Dengan adanya motivasi, peserta didik akan belajar lebih keras, tekun, ulet serta memiliki konsentrasi yang penuh dalam proses belajar pembelajaran. Adanya dorongan motivasi dalam belajar menjadi salah satu hal yang harus dibangkitkan dalam upaya pembelajaran di sekolah.

Namun selama ini pembelajaran yang disampaikan masih bersifat konvensional dan monoton, berpusat pada guru, peserta didik kurang aktif, serta kurang kreatif dan belum menggunakan model dan media pembelajaran yang bervariasi sehingga hasil belajar rata-rata pada materi pertumbuhan dan pembangunan ekonomi pada kelas XI.MIPA1 di SMA Negeri 3 Pemalang masih dibawah batas minimum yaitu 56,67\% sedangkan motivasi belajar peserta didik masih rendah sebesar $39,88 \%$. Hal ini tentunya menjadi perhatian bagi peneliti untuk merubah pembelajaran agar pembelajaran lebih bervariasi dan peserta didik lebih kritis salah satunya menggunakan model pembelajaran yang bervariasi dan dibantu dengan penggunaan media yang sesuai.

Pembelajaran kooperatif merupakan bentuk pembelajaran dengan cara peserta didik belajar dan bekerja dalam kelompok kecil secara kolaboratif dengan strukur kelompok yang bersifat heterogeny (Rusman, 2010:202). Student Teams Achievement Division (STAD) adalah pembelajaran yang mengelompokan peserta didik di dalam kelas menjadi kelompok belajar yang beranggotakan 4-6 peserta didik, setiap kelompok haruslah heterogen, terdiri dari laki-laki dan perempuan, berasal dari berbagai suku, memiliki kemampuan tinggi, sedang, dan rendah. Pembelajaran Kooperatif Tipe Student Teams Achievement Division (STAD) merupakan pembelajaran yang diterapkan pada peserta didik dengan cara berdiskusi untuk memacu peserta didik berpikir kritis baik dalam menemukan masalah maupun dalam upaya menyelesaikannya, serta dilatih menjawab kuis secara perseorangan.

Smart Apps Creator (SAC) merupakan aplikasi desktop untuk membuat aplikasi berbasis mobile dan IOS tanpa kode pemprograman, serta dapat menghasilkan format HTML dan exe. Kelebihan dari smart apps creator merupakan tool multimedia yang sangat mudah karena bisa dibuat tanpa programming sehingga guru yang tidak mempunyai latar belakang programming dapat membuat mobile apps dengan baik dan menarik, tampilan yang mudah dimengerti, dan tidak memakan banyak ram. Kekurangannya yaitu hanya dapat membuat aplikasi sederhana. Smart apps creator di dukung oleh berbagai feature dan tools untuk mempermudah pembuatan media. Diantara kegunaan tools nya adalah menu insert atau untuk memasukkan gambar, musik, video, teks dan lain sebagainya, menu edit untuk mengatur atau merapikan teks, menu interaction untuk memberikan efek pada gambar atau animasi.

Menurut Uno (2011) bahwa motivasi belajar merupakan dorongan internal dan eksternal pada peserta didik yang sedang belajar untuk mengadakat tingkah laku, pada umumnya dengan beberapa indicator atau unsur-unsur yang mendukung. Indikator tersebut antaralain: adanya Hasrat dan keinginan berhasil, dorongan dan kebutuhan dalam belajar, harapan dan cita-cita masa depan, penghargaan dalam belajar serta lingkungan belajar yang kondusif. Motivasi belajar juga merupakan salah satu faktor yang turut menentukan keefektifan dalam pembelajaran. Seorang peserta didik akan belajar dengan baik apabila ada faktor pendorongnya yaitu motivasi belajar. Peserta didik akan belajar dengan sungguh-sungguh jika memiliki motivasi belajar yang tinggi.

Dimyati \& Mudjiono (2013) " menyatakan bahwa hasil belajar merupakan hasil dari suatu interaksi tindak belajar dan tindak mengajar. Dari sisi guru, tindak mengajar diakhiri dengan proses evaluasi hasil belajar. Dari sisi siswa, hasil belajar merupakan berakhirnya penggal dan puncak proses belajar".

Beberapa penelitian terdahulu yang pernah dilakukan (Faridah, D., Connie., \& Medriati, R., 2018) menyatakan bahwa model pembelajaran kooperatif tipe STAD dengan memanfaatkan media audiovisual dapat meningkatkan motivasi belajar siswa. Begitu juga dengan penelitian (Dhewani, M.A., Yamtinah, S., \& Martini, K.S., 2015) bahwa pembelajaran STAD dilengkapi dengan LKS dapat meningkatkan motivasi dan prestasi belajar peserta didik pada materi reaksi kimia di SMP Negeri 19 Surakarta. Menurut (Wardana, S., \& Sagoro, E.M., 2019) bahwa 
Impelementasi model pembelajaran Gamifikasi Berbantu Media Kahoot dapat meningkatkan Aktivitas Belajar, motivasi, dan hasil belajar siswa kelas X Akuntansi 3 SMK Koperasi Yogyakarta Tahun Ajaran 2018/2019.

Dengan penggunaan model pembelajaran yang efektif dan dengan pemilihan media pembelajaran yang tepat maka peserta didik akan lebih senang dalam melakukan pembelajaran. Peserta didik juga akan mengeksplor kemampuan mereka secara maksimal dalam pembelajaran. Dengan demikian berpengaruh terhadap peningkatan motivasi dan hasil belajar peserta didik. Dengan penerapan model STAD berbantu SAC akan menciptakan suasana belajar yang lebih menyenangkan. Peserta didik dapat mengeksplor apa yang mereka pelajari dari materi yang mereka dapatkan sehingga dapat meningkatkan kemampuan peserta didik untuk memahami dan mencapai keberhasilan belajar pada materi pertumbuhan dan pembangunan ekonomi. Dari uraian di atas maka peneliti tertarik untuk melakukan penelitiann dengan judul "Penerapan Model STAD berbantu SAC Untuk Meningkatkan Motivasi dan Hasil Belajar peserta Didik".

\section{METODE PENELITIAN}

Penelitian tindakan kelas ini dilaksanakan di SMA Negeri 3 Pemalang pada peserta didik kelas XI.MIPA1 dengan fokus materi pertumbuhan dan pemmbangunan ekonomi. Sumber data yang dibutuhkan dari nara sumber, dokumen, dan proses pembelajaran. Teknik pengumpulan data penelitian ini dengan menggunakan non tes yaitu wawancara peserta didik, kuesioner, dan observasi terhadap proses pembelajaran , sedangkan untuk mengukur hasil belajar peserta didik dengan menggunakan tes berupa soal pilihan ganda. Instrumen yang digunakan dalam penelitian ini menggunakan lembar observasi, lembar angket, dan tes. Penelitian ini menggunakan analisis kuantitatif dengan teknik presentase dan deskriptif kualitatif. Indikator kinerja yang inin diperoleh dalam penelitian tindakan kelas ini adalah meningkatnya motivasi dan hasil belajar pada materi pertumbuhan dan pembangunan ekonomi dengan menerapkan método STAD berbantu media SA. Sebagai ukuran keberhasilan dalam pelaksanaan penelitian tindakan kelas ini apabila peserta didik yang nilainya mencapai KKM yaitu 70 dan persentase ketuntasan klasikal peserta didik mencapai lebih dari $80 \%$. Penelitian ini dilaksanakan dalam dua siklus yang terdiri dari empat tahap yang meliputi tahap perencanaan, pelaksanaan, observasi, dan refleksi.

\section{HASIL DAN PEMBAHASAN}

\section{Hasil}

\section{Peningkatan Motivasi Belajar}

Peningkatan motivasi belajar peserta didik kelas XI.MIPA1 SMA Negeri 3 Pemalang dapat dilihat pada diagram di bawah ini.

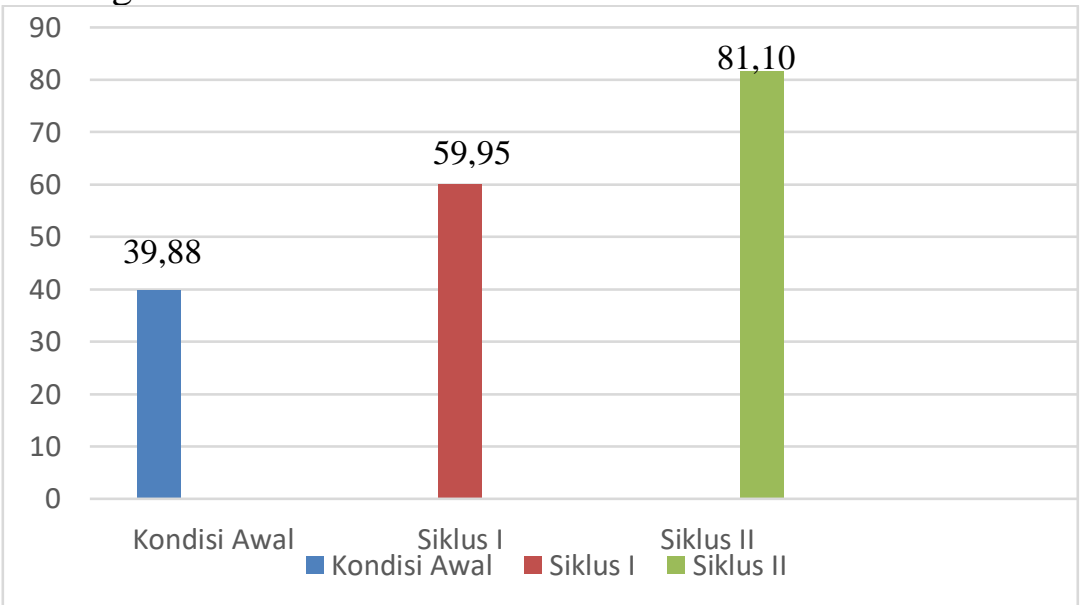

Gambar 1 Grafik Peningkatan motivasi belajar peserta didik 
Dari gambar di atas dapat dilihat peningkatan motivasi belajar peserta didik kelas XI.MIPA1 SMA Negeri 3 Pemalang. Pada kondisi awal motivasi belajar peserta didik sebesar $39,88 \%$ meningkat $59,95 \%$ pada siklus I, dan $81,10 \%$ pada siklus II. Peningkatan motivasi belajar peserta didik dipengaruhi oleh penggunaan model pembelajaran STAD berbantu media pembelajaran mobile berbasis SAC. Dalam proses pembelajaran guru memperkenalkan media pembelajaran yang tidak biasa digunakan oleh guru sebagai langkah awal untuk mendorong rasa ingin tahu peserta didik. Kemudian guru menyampaikan tujuan yang ingin dicapai pada materi pertumbuhan dan pembangunan ekonomi. Guru membagi peserta didik menjadi beberapa kelompok. Peserta didik membaca petunjuk penggunaak apk SAC. Guru memberikan masalah pada apk SAC agar peserta didik berdiskusi dengan anggota kelompoknya. Peserta didik membacakan hasil diskusinya dan guru memberikan kesimpulan dari hasil diskusi para peserta didik.

Berdasarkan data yang telah diperoleh di atas, peneliti menyimpulkan bahwa penerapan model STAD berbantu media pembelajaran mobile berbasis SAC dapat meningkatkan motivasi belajar peserta didik. Peningkatan motivasi belajar peserta didik terlihat ketika peserta didik aktif berdiskusi di dalam pembelajaran jarak jauh, ataupun terbuka dengan hal-hal baru baik bertukar pendapat ataupun mengemukakan ide dalam kelompok. Media mobile berbasis SAC di desain agar peserta didik tidak bosan, bisa dipelajari berulang-ulang, belajar sambal mendengarkan musik, materi bisa dibaca atau bisa didengarkan. Di dalam isi apk SAC juga didesain lengkap ada materi, LKPD, Latihan mandiri serta evaluasi. Apk SAC didesain bisa digunakan menggunakan kuota maupun tanpa kuota. Dengan desain yang interaktif bertujuan agar motivasi belajar peserta didik meningkat

\section{Peningkatan Hasil Belajar}

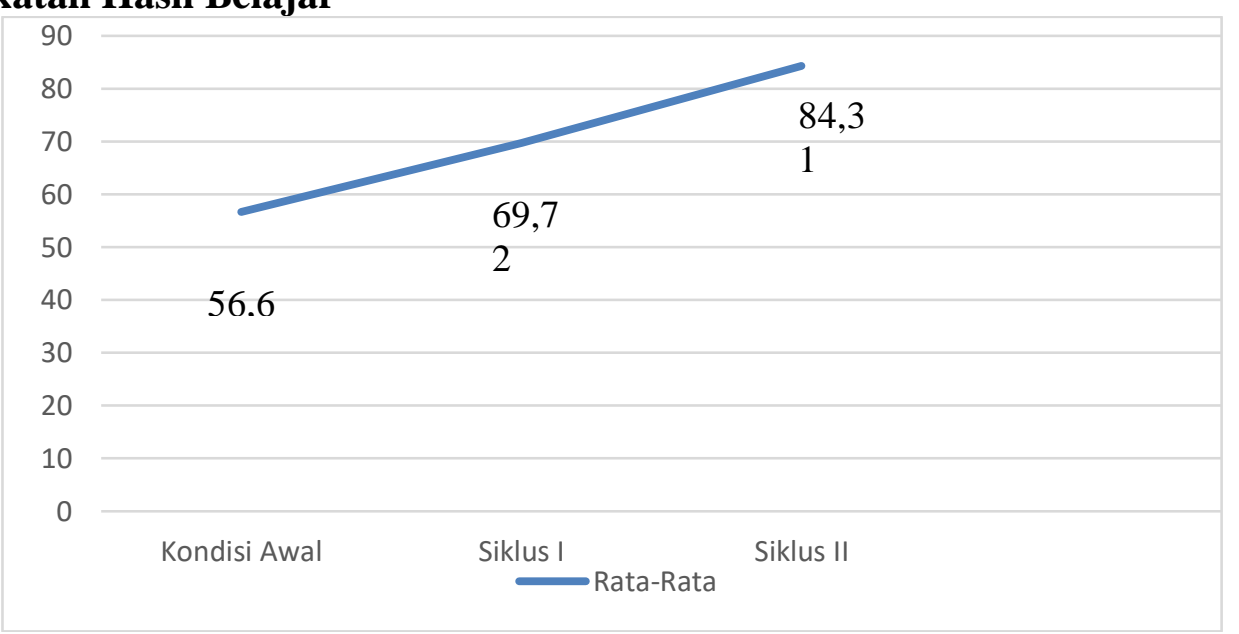

Gambar 2. Grafik Peningkatan Hasil Belajar Peserta Didik

Dari gambar di atas dapat dilihat peningkatan rata-rata hasil belajar peserta didik kelas XI.MIPA1 SMA Negeri 3 Pemalang. Dari kondisi awal belajar peserta didik sebesar 56,67 meningkat menjadi 69,72 pada siklus I, dan 84,31 pada siklus II. Melalui diagram pada gambar 3 diketahui nilai rata-rata ulangan siswa pada siklus I sebesar 69,72. Dari hasil yang diperoleh ada 27 peserta didik dengan presentase $75 \%$ sudah mencapai KKM, dan 9 peserta didik belum mencapai KKM dengan presentase 25,00\%. Dengan standar nilai KKM yang sudah ditentukan yaitu 70. 


\section{Persentase KKM Siklus I}

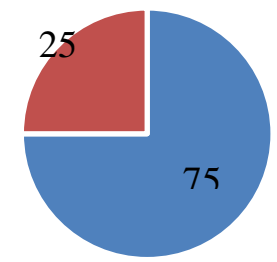

- Peserta Didik Sudah Mencapai KKM - Peserta Dididk Belum Mencapai KKM

\section{Gambar 3. Diagram Peningkatan Persentase KKM}

Siklus I Diagram di atas menunjukkan bahwa telah ada peningkatan pencapaian hasil belajar ekonomi pada materi pertumbuhan dan pembangunan ekonomi dibanding dengan kondisi awal. Kondisi awal terdapat 8 jumlah peserta didik, yang sudah mencapai KKM ada 28 peserta didik dengan persentase $22,22 \%$ dan peserta didik belum mencapai KKM ada 5 dengan persentase $77,78 \%$. Melalui diagram pada gambar 4 diketahui nilai rata-rata ulangan peserta didik pada siklus II sebesar 84,31. Dari hasil yang diperoleh ada 31 peserta didik dengan persentase $86,11 \%$ sudah mencapai KKM, dan 5 peserta didik belum mencapai KKM dengan persentase $13,89 \%$. Dengan standar nilai KKM yang sudah ditentukan yaitu 70 . Berdasarkan data tersebut, maka dapat digambarkan persentasepencapaian hasil belajar siswa pada siklus II sebagai berikut.

\section{Persentase KKM Siklus II}

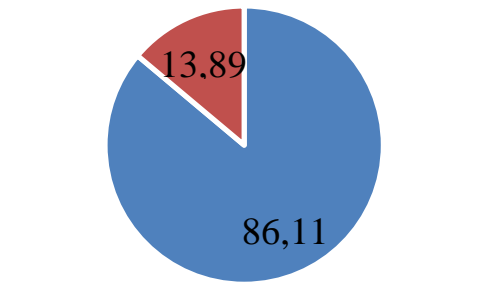

- Peserta Didik Sudah Mencapai KKM

- Peserta Didik Belum Mencapai KKM

\section{Gambar 4. Diagram Peningkatan Persentase KKM}

pencapaian hasil belajar Ekonomi pada materi pertumbuhan dan pembangunan ekonomi siklus II dibanding dengan siklus I. Persentase pencapaian KKM siklus I 75,00\%, sedang persentase pencapaian KKM siklus II $86,11 \%$ dengan selisih persentase $11,11 \%$ telah mengalami peningkatan.

\section{Pembahasan}

Berdasarkan hasil analisis data tingkat ketuntasan dan hasil belajar siklus I mencapai 75\% dengan rata-rata 69,72 dari 56,67. Dengan peningkatan nilai hasil belajar 13,05. Pada Pelaksanaan tindakan siklus II mencapai $86,11 \%$ dengan rata-rata 84,31. Peningkatan prestasi belajar peserta didik dari nilai rata-rata kelas 69,73 menjadi 84,31 adanya peningkatan nilai hasil belajar 14,58.

Peningkatan hasil belajar peserta didik dipengaruhi dengan adanya proses pembelajaran dengan menggunakan model STAD berbantu media mobile berbasis SAC. Peserta didik menyukai hal-hal baru, dengan begitu perlu proses pembelajaran menarik yang mampu memotivasi dalam belajar. Dalam hal ini media mobile berbasis SAC dapat menjadi salah satu 
alternatif dalampembelajaran inovatif. Melalui beberapa langkah media mobile berbasis SAC seperti penyampaian cara penggunaan apk SAC membantu peserta didik memberi dorongan untuk belajar dari rasa ingin tahunya. Hal ini terlihat saat tanya jawab peserta didik mencarimencari jawaban dari sebuah permasalah seperti penayangan video tentang berita pertumbuhan ekonomi. Peserta didik berdiskusi dengan kelompoknya lalu pada saat presentasi adanya keaktifan dari peserta didik untuk berdiskusi dalam pembelajaran jarak jauh. Dengan demikian melalui penerapan model STAD berbantu media pembelajaran mobile berbasis SAC dapat membantu peserta didik dalam proses pembelajaran untuk terlibat aktif dan kreatif dengan jawaban dalam diskusinya sehingga dapa meningkatkan motivasi belajar peserta didik dan hasil belajar meningkat.

Hal ini sejalan dengan penelitian (Anwar, K.A., Karmana, I.W., \& Harisanti, M., 2017) bahwa penggunaan model STAD berbantu Macromedia Flash dapat meningkatkan motivasi dan hasil belajar peserta didik karena dengan penggunaan media pembelajaran menjadikan pembelajaran lebih menarik dan memusatkan perhatian peserta didik. Begitu pula pendapat (Legiman, 2020) bahwa pemanfaatan model pembelajaran kooperatif tipe STAD berbantu alat peraga dapat meningkatkan keaktifan dan peningkatan hasil belajar peserta didik.

Menurut (Pradikto, B., Purnama, I., \& Janjumari, R., 2021). Bahwa pembelajaran menggunakan model kooperatif tipe STAD dengan media Kahoot! dapat meningkatkan aktivitas warga belajar dalam belajar mengajar dan terjadi perubahan tingkah laku secara intelektual dan lebih aktif dalam menggali materi dan menciptakan pembelajaran yang menyenangkan. Sedangkan menurut (Aryana, K.D.T., Pudjawan, K., \& Kusmariyatni, N., 2016) bahwa penerapan model pembelajaran kooperatif tipe STAD berbantu media audio visual sangat membantu serta mempermudah kegiatan belajar peserta didik dalam pembelajaran IPA sehingga dapat merangsang aktivitas dan menunjang hasil belajar peserta didik dengan optimal.

Belajar dikatakan berhasil apabila selama proses pembelajaran terjadi perubahan yang positif baik dari guru maupun peserta didik. Guru menggunakan model dan media pembelajaran yang bervariasi sehingga bisa menarik minat peserta didik untuk belajar, peserta didik menjadi lebih kritis, kreatif dan bahkan berinovasi dalam belajarnya. Dengan penggunaan model dan media yang bervariasi diharapkan akan terjadi peningkatan motivasi dan hasil belajar peserta didik.

\section{KESIMPULAN}

Berdasarkan hasil penelitian dan pembahasan dalam penelitian ini maka dapat disimpulkan bahwa: 1) Penerapan model STAD berbantu media pembelajaran mobile berbasis SAC dapat meningkatkan motivasi belajar peserta didik dalam mata pelajaran ekonomi pada materi pertumbuhan dan pembangunan ekonomi. Hal ini ditunjukkan pada peningkatan ratarata skor motivasi belajar peserta didik dari kondisi awal 39,84 (rendah), pada siklus I menjadi 59,85 (sedang), dan pada siklus II menjadi 81,10 (tinggi); 2) Penerapan model STAD berbantu media pembelajaran mobile berbasis SAC dapat meningkatkan hasil belajar peserta didik dalam mata pelajaran ekonomi pada materi pertumbuhan dan pembangunan ekonomi. Hal ini ditunjukkan pada peningkatan nilai rata-rata ulangann harian peserta didik dari kondisi awal 56,67, pada siklus I diperoleh nilai 69,72, dan pada siklus II menjadi 84,31. Persentase jumlah peserta didik yang mencapai KKM (70) meningkat dari kondisi awal 22,22\%, pada siklus I menjadi $75 \%$, dan pada siklus II menjadi $86,11 \%$. Dengan demikian, media pembelajaran mobile berbasis SAC bisa diterapkan untuk pembelajaran pada mata pelajaran lain.

\section{DAFTAR PUSTAKA}

Anwar, K.A., Karmana, I.W., \& Harisanti, M. (2017). Peningkatan Aktivitas dan Hasil Belajar Matematika Pada Materi Bangun Ruang Sisi Datar Melalui Model Pembelajaran Kooperatif Tipe STAD Berbantuan Alat Peraga. Jurnal Prakarsa Paedagogia, Vol. 5 No.2, ISSN 2338-5006, 
Aryana, K.D.T., Pudjawan, K., \& Kusmariyatni, N. (2016). Penerapan Model Pembelajaran STAD Berbantu Media Audio Visual untuk Meningkatkan Aktivitas dan Hasil Belajar IPA. Mimbar PGSD Undhiksa, Vol 4, No 1, htts:p//ejournal.undiksha.ac.id/index.php/JJPGSD/article/view/6955.

Dhewani, M.A., Yamtinah, S., \& Martini, K.S. (2015). Penerapan Model Pembelajaran STAD (Student Teams Achievement Division) Dilengkapi dengan LKS untuk Meningkatkan Motivasi dan Prestasi Belajar pada Materi Reaksi Kimia Siswa Kelas VII SMP Negeri 19 Surakarta. Jurnal Pendidikan Kimia (JPK), Vol. 4 No. 1, https://jurnal.fkip.uns.ac.id/index.php/kimia/article/view/5202.

Dimyati \& Mudjiono. (2013). Belajar Dan Pembelajaran. Jakarta: Rineka Cipta.

Faridaf, D., Connie., \& Medriati, R. (2018). Penerapan Model Pembelajaran Kooperatif Tipe Student Team Achievement Division (STAD) dengan Memanfaatkan Media Audiovisual untuk Meningkatkan Motivasi Siswa SMPN 1 Pondok Kubang. Jurnal

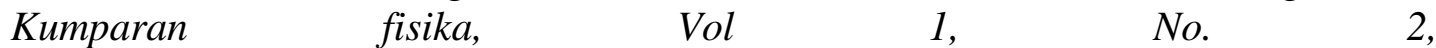
https://ejournal.unib.ac.id/index.php/kumparan_fisika/article/view/6224.

Legiman, A. (2020). Peningkatan Aktivitas dan Hasil Belajar Matematika Pada Materi Bangun Ruang Sisi Datar Melalui Model Pembelajaran Kooperatif Tipe STAD Berbantuan Alat Peraga. Jurnal Prakarsa Paedagogia Vol. 3 No. 2, https://jurnal.umk.ac.id/index.php/JKP/article/view/5742/pdf

Pradikto, B., Purnama, I., \& Janjumari, R. (2021). Penerapan Model Pembelajaran Kooperatif Tipe STAD Menggunakan Aplikasi Kahoot Dalam Meningkatkan Hasil Belajar Pada Pendidikan Kesetaraan Paket C. Jurnal Ilmu Pendidikan Non Formal Vo 7, No.2, http://ejurnal.pps.ung.ac.id/index.php/Aksara/article/view/492.

Uno, Hamzah B (2011). Teori Motivasi dan Pengukurannya: Analisis di Bidang Pendidikan. Jakarta: Bumi aksara.

Wardana, R \& Sagoro, E.M. (2019). Implementasi Gamifikasi Berbantu Media Kahoot untuk Meningkatkan Aktivitas Belajar, Motivasi Belajar, dan Hasil Belajar Jurnal Penyesuaian siswa Kelas X Akuntansu 3 di SMK Koperasi Yogyakarta tahun Ajaran 2018/2019. Jurnal Pendidikan Akuntansi Indonesia Vol.XVII, No.2, https://journal.uny.ac.id/index.php/jpakun/article/view/28693. 